\title{
Book culture, landscape and social capital: The case of Maleny
}

\author{
Jane Frank \\ j.frank@griffith.edu.au
}

\begin{abstract}
The clustering of book culture in rural locales around the world is a growing phenomenon. Creative and cultural activity in these bookish communities enhances social capital, and their book-based economies contribute to sustainability. Maleny, in South-East Queensland's Sunshine Coast hinterland, has long been recognised as a centre for books, readers and writers. It is the home of two writers' festivals, Outspoken and Maleny Celebration of Books. The community attracts city dwellers, and those who like to escape to the Blackall Ranges for relaxation, as well as people who choose to live a 'slow' life in the area. Onyx (2005) identified high levels of social capital. In this article, I consider the potential of Maleny to position itself as a 'book town'. However, my findings confirm that, despite the community's reputation as a place of cultural consumption, prosperity is a hindrance to book town development.
\end{abstract}

\section{Introduction}

In 2015 I completed doctoral research on the International Book Town Movement ${ }^{1}$, focused on the impacts of book towns on the cultural sphere, as powerful sources of creativity. Part of my research included investigating the potential of the concept for cultural generation in Queensland. A cluster of towns in the Southern Highlands of New South Wales and the town of Clunes in Victoria have developed as book towns over the last fifteen years.

My interest in these Australian examples led me to consider the potential of Maleny in the Sunshine Coast hinterland as a book town location. The town's book culture was drawn to my attention during the course of my research by experts in both publishing and tourism. Book culture is an important contributor to Maleny's economy and the ethos of the town. My interest is in the way Maleny has emerged as a cultural landscape in which book-based activity has imbued this hinterland area with cultural values.

A study by Jenny Onyx (2005) assessed social capital and sustainable development in Maleny, citing high levels of cooperation and cohesion. Survey data demonstrated that Maleny recorded the highest social capital factor across seven different rural and urban communities Australia-wide (Onyx and Bullen 2000). My research showed that high social capital is linked to book town success in other 
places. However, Onyx also highlighted the risk factors for prosperous communities like Maleny, rich in social capital in beautiful environmental settings, whose desirability may eventually become the cause of their demise (Onyx 2005: 3). Onyx's views contributed to my own thinking about Maleny's cultural development, the ways prosperity can inhibit creativity and how such a challenge can be overcome.

The term 'social capital' has gained currency, most notably through the works of Bourdieu $(1986,1984)$ and Putnam $(2000,1995)$. In his studies of Italian communities, Putnam's over-arching finding was that any increase or decrease in the level of social capital in a community would lead to a corresponding decline in the quality of life within that community. Social capital and strong communities are therefore closely linked. A strong community exhibits high levels of coordination and cooperation for reciprocal and mutual benefit, resulting in lively civic engagement and effective collective actions. Creative and cultural activity enhances social bonds in places where there are high levels of book culture. Positive outcomes from arts experiences - such as the communal meaning arising from mass participation at a rural locality - and those that accrue over time - such as preserving cultural heritage and fostering cultural diversity - contribute to cohesion. The book itself provides a platform for social interaction that resonates in a global culture, where the unique and the particular are increasingly sought after. Book culture at literary events can be likened to a 'kind of conversation' (Zaid 2004: 40) as book enthusiasts cluster around authors, books, bookstores and community activities in much the same way they gather together to take part in a life-affirming dialogue. This is achieved not only through participating writers and artists but through the involvement of other community members motivated by a sense of obligation and pride in their community. This engagement is also sought by visitors seeking escape, relaxation and cultural amenity.

This article examines Maleny's community and its book culture using a qualitative approach that provides insights that quantitative research on social cohesion is unable to fully capture. It discusses Maleny's accelerating focus on book culture in the ten years since Onyx's research, and looks at the way the community has fashioned itself as a tourism destination that provides visitors with pleasurable intellectual immersion, inspiration and rejuvenation centred on book-based leisure and landscape. The article describes the scope of book culture in Maleny, including its festivals, its growing entrepreneurship and its reliance on cultural tourism for sustainability. I aim to uncover the reasons why book culture seems to work in Maleny to support and enhance the creativity and resilience of the population, how it underpins the way the town models itself as a place of aesthetic values and ethical practices, and how slowly consumed book-based pursuits deliver rural sustainability.

Site-based research was central to this case study. My investigation of Maleny involved becoming familiar with the structure, networks, partnerships and social issues that exist in the town. This included developing an understanding of the community's political and social make-up, local history, geography and cultural resources. My ethnographic approach was grounded in my own first-hand experience of Maleny over many years. This long-term exploration of the town was a basis for more focused participant observation, using Maleny's cultural setting as a data source (Mason 2002: 55). I observed community dynamics at events and festivals, as well as in the day-to-day life of the town. 
Through its cultural development, Maleny has accrued new layers of meaning that can be analysed through historical, sociological and cultural perspectives. This inquiry into the dynamics of the community of Maleny revealed new insights into the limits of social cohesion. From the perspective of my book town research, it showed that some requirements for book town success were not present in the community.

In addition to participant observation, I conducted a number of semi-structured interviews and engaged in conversations with key cultural and community figures, to gain a broad understanding of the social realities in Maleny. I also considered how people made decisions and participated in social action. My research had sparked interest in the book town concept, and I was invited by members of the Maleny Arts Council to advocate for Maleny's potential as a book town at a public meeting in Maleny in 2012. As keynote speaker and a discussion panel member, I was able to observe the views expressed by different community group representatives on the panel, and other meeting attendees as they responded. While some sections of the community were open to debate and discussion, this event and other subsequent communications revealed divisions in opinion and disclosed a limit to Maleny's inclusiveness that reinforces Onyx's concerns about Maleny's future sustainability.

\section{Maleny's book culture}

Maleny is located on the Blackall Ranges in the Sunshine Coast hinterland, a leisurely hour's drive north of Brisbane. A new bookstore, Rosettas, and two quality secondhand bookstores, Maleny Book Shop and ps Books, are nestled among bakeries, organic food shops and cafés in the town's main street. Other businesses also sell books. There is a thriving library culture, dozens of book clubs, a number of poetry and writing groups and Jill Morris's book farm. Maleny hosts many other literary events and celebrations. Over 500 artists of different genres live in the hinterland, many of them writers - including Morris, Gary Crew, Steven Lang, Inga Simpson, James Cowan and Ross Watkins. Permeating the book culture in Maleny is a genuine appreciation of the environment and our responsibility for protecting it.

Although there have been books and writing events in Maleny's past, the introduction of two successful literary festivals in Maleny - Outspoken and Celebration of Books Maleny - has deepened this town's engagement with literary culture. In 2010, environmentalist and author Steven Lang and antiquarian book dealer Chris Francis established Outspoken (Lang 2015b), an extended literary festival taking the form of occasional conversations with writers. Forty-nine of these events have now occurred, and the festival has been successful in securing national and international writers such as Tim Flannery, Magda Szubanski, Geraldine Brooks, Richard Ford, Thomas Keneally, Richard Flanagan, Ramona Koval, Patrick Gale, Kate Grenville, Karen Joy Fowler, Ruth Ozeki and Cate Kennedy.

People from Brisbane and the wider Sunshine Coast join enthusiastic locals at these events. The success of the initiative depends on the town's open-minded and curious residents, who are committed to their community (Lang 2015a; Maleny Arts Council 2012). The unique setting and professionalism of these events attract authors and publishers alike. Maleny is 'on the map' for Australian author tours, not only to Outspoken but to Rosetta Books events, and authors request Maleny as 
a destination to enjoy time in this beautiful part of the country. The fact that Lang is an informed interviewer and the audiences ask intelligent, thought-provoking questions also enhance authors' enjoyment. Publishers relish the sold-out audiences and the opportunity to sell books and raise their profiles (Lang 2015a; Maleny Arts Council 2012).

Following this, in 2012 a group of reading enthusiasts and like-minded booklovers collaborated to create an annual boutique community event celebrating Maleny's love of books, reading and writing. The team of coordinators comprised a mix of people, all with a commitment to the wellbeing of the town and to the town's reading community (Radbourne 2015) - local booksellers, librarians, academics, authors, arts workers, artists and teachers. Celebration of Books Maleny, which had occurred each October until 2015 when it was brought forward to July, features workshop events, book launches, films, interviews with writers, a writers' marketplace, a book club gathering and a book swap tree in Cooke Park in Maleny's main street. Here you hang a book you've enjoyed on a tree and select another one left by a fellow reader.

The event has gone 'from strength to strength', with the Big Book Club Gathering and the author forums in particular attracting a growing level of interest. Joint project leader Jennifer Radbourne (2015) attributes this success to the level of genuine commitment to cultural interactions in Maleny and the invaluable contributions from the library and the bookshops. The author forums, where local and Brisbane authors showcase their talent, emphasise the link between landscape and literature, with a keen focus on place and country, which Radbourne considers important to deepening the reader's engagement with place and narrative. She stresses the emphasis of this festival on readers and their experiences, rather than the writers. The festival aims to maximise the pleasure of readers at a relaxed event hosted in an environment of great scenic beauty.

Some 75 per cent of Maleny's population belong to the library, well exceeding the national average of 49 per cent. This population also exhibits unusually high levels of library borrowing, volunteerism and uptake of both adult education and children's programs (Maleny Arts Council 2012). The library has promoted the joy of reading in this community through a number of key partnerships. One of these is the Gary Crew Reader's Club. Maleny author and University of the Sunshine Coast (USC) academic Gary Crew works with teachers and a small committee, including library staff, to compile an annual list of books that the Maleny children read at school. They then take part in quizzes and competitions, where Crew awards prizes of medals and book vouchers. Crew, the winner of a Wilderness Society national award for his Extinction series of children's books, encourages an attitude of caring and responsibility towards the environment, and an awareness of environmental problems and possible solutions. Likewise, Rosetta's Bookshop has connections 'right through the community' with books: with the library, the local schools, book clubs and the Film Society. They host exhibitions for Collaboration of Maleny Artists (COMA), actively support local festivals such as the Wood Expo and the Real Food Festival, and run frequent author evenings and events.

Award-winning children's author and publisher Jill Morris, whose company Greater Glider Productions has published approximately 50 authors and illustrators, is a long-standing advocate of books, book illustration and publishing in the 
Maleny area. Morris lives on a farm that 'grows books' - she calls it a book farm and inspires children to interpret their feelings about the natural environment. The book farm has received national Eco Certification for Morris's encouragement of nature experiences that lead to a greater understanding of sustaining the environment for future generations. Writers of all ages are able to explore the rainforest with published authors and illustrators, as well as to experience the writing, illustrating and publishing process at Greater Glider Productions. In a discussion about Maleny's identity as a location for books, readers and writers, Jill Morris states:

Everything that I say to you is coloured by getting older and being very connected to the land here ... Everything I've ever done in theatre, publishing, writing, editing and now film production is about the sustainability of land and the rainforest and wildlife. (Maleny Arts Council 2012)

Maleny is a location where landscape meets literature. This is enhanced by the capacity of the residents for creativity and resilience relating to the town's past, as well as the growing desirability for book-based tourism and 'slow' pursuits that deliver sustainability.

\section{Slow books: A 'meaningful' tourism offering}

The clustering of book culture in rural locales around the world is a growing phenomenon, and while Maleny is not a book town per se, it shares characteristics with other book towns and literary communities that have become increasingly important sources of creativity and influential sites in the cultural sphere. As a location for rural escape, Maleny embodies many characteristics of the Slow Movement, a cultural revolution that resists the notion that faster is always better. First emerging in Italy in the early 1990s, the Slow Food Movement helped redefine the word 'slow' as positive - it centred on buying local produce and enjoying regional flavours. Slow travel offers richer experiences of places focusing on terroir - the uniqueness of place - and what Dickenson and Lumsden (2010) call an avoidance of 'staged authenticity'. The focus, they argue, should be on the vernacular, local distinctiveness and place-based knowledge. The Slow Movement is also a sophisticated response to unsophisticated, vacuous commercialism, and offers experiences that are life-affirming and rooted in a deep understanding of human needs for wellbeing, rejuvenation and immersion in the natural environment; for solitude and space, but also intellectual stimulation. The slow ethos is closely linked to why people seek out leisure experiences, such as fossicking for old books, attending festivals, film nights, concerts and workshops, and particularly wanting to enjoy these experiences in a small rural community.

A desire to flee the city and visit the Blackall Ranges is about accessing a range of experiences - environmental, social, economic - that are not associated with conventional 'mass' tourism. They relate to a range of ethical considerations. For Brisbane residents, weekend visits to Maleny answer the need to create personal connections with natural landscapes and to preserve sacred spaces in daily life. Occupying these spaces represents 'a metaphorical ... flight from the city, a desire for emotional and intellectual, as much as physical, distance from urban lifestyles' (Mulcock and Toussaint 2002: 1). The haste and relentlessness associated with city existences are counteracted by opportunities for meaningful attachments in places 
like Maleny; it provides an alternative to the contemporary shopping centre, high street and department store, which are 'utterly boring and predictable' and the same in each state - even each nation (Franklin 2008: 8-9). The merchandise available in Maleny introduces an element of serendipity to shopping that provides a new type of novelty - ironically, a commercial value.

In Maleny, it is possible to embrace unique specialty activities that are intrinsically linked with the natural - farmers' markets, boutique factories that produce ice cream and cheese, wineries, hand-sewn garments, old books and antiques, and so on. Urry (1988: 42) writes of

the middle class obsession with health foods, real ale, real bread, vegetarianism, traditional non-western science and medicine, natural childbirth, wool and cotton rather than artificial fibres, antiques rather than reproductions, old houses rather than modern houses, cycling, walking and mountaineering rather than contrived organised leisure.

The appeal of both new and antiquarian book hunting and the rustic small-town atmosphere of the Blackall Ranges correlates with that ethos of wholesomeness that is intrinsic to Maleny's history. Slow experiences are sold as a means to fix ills in people's lives through amenities that promote connectedness to people, food, place and community. Bookshops, book events, and indeed Maleny itself fill a void by providing a destination for acquaintance, conviviality and human interaction, as well as space and solitude. This experience also supports social cohesion by bringing together people with overlapping interests. The slow travel paradigm offers one of a number of definite paths towards the overall goal of sustainable tourism. The Western obsession with cheap goods that have a short lifespan and a high turnover are being challenged through 'connected consumption' patterns that re-use goods (Schor, in Sassatelli 2013: 181). The appeal of the secondhand market central to shopping in Maleny - vintage clothing, handmade goods, antiques, antiquarian books and the rustic village atmosphere - correlates with an ethos of 'wholesomeness'.

Part of the pressure facing the publishing sector is also environmental, particularly with relation to the use of increasingly scarce natural resources. In the current climate, the sustainability of 'ungreen traffic in dead trees that lies at the root of the great paper-based empires - newspapers, magazines, direct mail and books' is questioned constantly (Brass, in McCrum 2006). The secondhand book market, in particular, appeals to a growing number of people who appreciate that the books are recycled, and this is predicted to be an escalating trend. Additionally, initiatives practised in book towns - such as book crossing and book-friendly communities, where books are encouraged to be 'set free' for interested readers to pick up or exchange - are regarded as environmentally friendly initiatives that increase the collective use of books. This slow consumption approach is linked to what Hall (2009) calls the notion of decroissance or degrowth, which has entered the lexicon of green economics in recent years. Maleny and the surrounding area support a number of the tenets of degrowth, emphasising quality of life rather than quantity of consumption as well as self-reflection, diversity, good citizenship and non-materialism. These qualities are embedded in Maleny's history. 


\section{The Maleny community: 'Concentric circles'}

When Onyx (2005) measured social capital across a number of Australian towns, Maleny registered the highest score for community connections, tolerance of diversity, trust and safety, and neighbourhood connections, and as a place of proactivity and social agency. Sensitivity to the natural environment was also a category measured by Onyx, who reported that a high percentage of the Maleny population surveyed believed reforestation, composting, recycling and development of renewable resources were important issues in their community (2005: 14). Her study revealed concentric circles of activity in Maleny that helped to preserve a unique social character, explaining the notion of these circles as communities within other communities, with no one over-arching community organisation or structure dominating and the circles rarely intersecting (2005: 29). Vital to the appeal of Maleny for residents is that it is an authentic place - a real place, not a manufactured place. Many educated people move to Maleny later in life, bringing their intellect and curiosity, which they want to apply in a 'different way', expressed in a 'whole of town commitment to the place that doesn't work if their motivation is purely commercial' (Radbourne 2015).

Maleny has a strong alternate community, which exists side by side with this growing number of ex-professional retirees and the more traditional farming families whose forebears settled the area from as early as the 1850 s, cutting timber to establish a dairy industry - although the differences among these groups have sometimes caused disharmony (Lang 2015a).

The new inhabitants of the 1970s pursued a community bolstered by more than a dozen cooperatives, which are maintained today, delivering community involvement, self-respect and also power throughout times of change. These cooperative origins are significant for the role they have played in the development of unusually strong community relationships. The Maple Street Food Coop was the first of these enterprises, 'opened ... because we wanted to eat lentils, brown rice and fresh vegetables - not the tired, tinned produce then offered by the local supermarket' (Tilden 1996: 1). The cooperative was based on principles prized by the community, such as social equality and community involvement. This was followed by the Maleny and District Credit Union, which kept money circulating within the area, allowing ethical investment and opening options to those not favoured by mainstream financial institutions (1996: 1). This led to the start of a Local Exchange and Trading System (LETS), a computer-based barter scheme. In Maleny, the LETS unit is called a 'bunya'. This system, still used by sections of the community and part of a nationwide umbrella with international links (Givens 2015), has buffered the Maleny economy during global economic swings, and has inspired more than 240 similar schemes now operating throughout Australia (Tilden 1996: 1). ${ }^{2}$

There is a radical undercurrent to these arrangements that implies a refusal to accept normalised modes of consumption. This becomes especially apparent when it is mobilised to protect the community, such as in the case of the Obi Obi campaign to prevent the building of a Woolworths store a few years ago, a significant milestone in the community's development. At this time, Maleny became a 'poster town for small communities fighting to exclude huge corporations' (Stafford 2005:22). Community concerns were underpinned by deeper disquiet about how the arrival of big business in Maleny might jeopardise the town's character. It is evident from 
that example, and many others over the years, that Maleny is a place that demonstrates resistance through localization, not only by protecting of its small town organic ethos but also by emphasising cultural traditions.

People are increasingly seeking to live in places where they feel a greater connection to their community, and this often means a move from an urban to a rural lifestyle where there is the much sought-after character or the aggregate of distinctive features that distinguishes one thing from another within a locale. Many residents of Maleny and the surrounding area are tree-changers who claim to seek a utopian lifestyle, free of many of the negative aspects of metropolitan living. Although, on the surface, the popularity of Maleny as an idealistic place to retire and a relaxing weekend destination appears to be motivated by a collection of individual and broad social needs for clean air, sociability, creativity, intellectual stimulation and slowness, escalating development in Maleny will continue to threaten the town's uniqueness.

However, research by Ragusa (2013) and others into the tree change trend suggests that, beyond listing undesirable attributes of city life and stereotypical hopes for a country alternative, few tree changers wish to fundamentally change their mode or standard of living: "Ultimately, perceptions of "enough" time, how and where to spend it, and which attributes are most or least meaningful are driven by historically and culturally contingent values, beliefs and social norms' (2013: 133). Ragusa argues that tree changers like to replicate aspects of the urbanity from which they appear to turn away when they seek out quiet country locales for respite. In fact, many of her informants sought communities as places of 'conspicuous consumption'. Publisher Laurie Muller (2010) makes a similar point:

It seems to me that people leave the urban thing for another semi-urban thing because everything has to be quality, the accommodation has to be close to the espresso shops and has to have a wellness centre pretty handy to it ... Weekend escapes ... are all really upmarket things. They are transplanted urban living in another place.

Although Ragusa's research and Muller's comments were not specifically directed to Maleny, my observations are that, in the same way, a sub-set of the category of tourists that flock to the Blackall Ranges are not so different to a growing post-tourist cohort that seeks a themed organic experience.

So far, Maleny has maintained the image of a real, functioning rural community - albeit one in which an alternative lifestyle prevails, ideas are traded and interesting people live. This is in stark contrast to the tourist town of Montville, 15 kilometres away, which has been manipulated in recent years to attract large busloads of tourists seeking a gentle, romanticised hinterland experience featuring cafés, craft and gift shops. The issue of the extent of authenticity that needs to be maintained in a town like Maleny will remain important to the middle-class cohort that supports it from Brisbane and elsewhere.

Property values in Maleny have escalated in recent years as a direct result of retirees flocking to the area to enjoy the remarkable scenery, community and lifestyle. On one hand, this brings wealth into the Maleny area. However, at that time, the higher property prices, rental costs and lack of career opportunities had resulted in younger people moving to the coast and elsewhere to live and work. ABS data indicating the low number of 20-35-year-olds living in Maleny supports this claim 
of a youth exodus (Onyx 2005: 27, 33). Ongoing residential and business development, a changing demographic and the rising cost of living are risks that threaten to impact the landscape and environment that delivers Maleny its point of difference. It is therefore a challenge for an area like the Blackall Ranges to maintain its distinctiveness, based around slow experiences - as well as developing and maintaining commercially viable enterprises. This requires a high level of sensitivity to the social eco-system of the community, comprising many different groups.

Tourist numbers are swollen by older Australians with time on their hands, 'grey nomads' trawling regional Australia seeking meaningful connections with communities and events as well as a sense of freedom and adventure through the pursuit of a nomadic lifestyle (Onyx and Leonard 2007: 381). They embrace the slow philosophy, tending to refuse high-tech modes of consumption, and instead supporting slow consumption (Hall 2009), as well as endorsing the preservation of the environment. This trend indicates a creative approach to living:

The availability of unobligated time experienced by many older individuals allows self-direction ... The need to break out of traditional ways of seeing the world and examining new paradigms underlies Ulyssean living. Loss of the work role and seeking the challenges of new roles can help accomplish this. (McGuire et al. 1999: 153).

Lifelong educational pursuits, social and environmental responsibility, and selfdevelopment through tourism are therefore powerful themes in Maleny, driving the growth of cultural and educational tourism experiences - whether heritage tourism, cultural tourism or eco-tourism.

\section{The problem with prosperity}

In 2012, following discussions about my doctoral research with members of the Maleny Arts Council, and a preliminary planning meeting, I was invited to present a keynote address and take part in a discussion panel at a public meeting to determine Maleny's potential to become a book town. This meeting proved a valuable opportunity to test not only community views about the book town concept, but also the power of book culture to underpin community debate. While many representatives from local government, USC, the library service, the hospitality industry and the general public in attendance were open to exploring this idea, most local booksellers and established writers present made it clear that the idea of theming the town was unattractive to them. They cited a number of reasons.

The first was that they did not believe the town had the capacity to support more booksellers due to the increasing rents resulting from Maleny's desirability and success. One speaker referred to the risks of rents escalating further as they had in the Welsh book town of Hay-on-Wye once it became it a mecca for international book tourists. They did not accept the idea that a town themed on books could assist the financial sustainability of the wider community through externalities. This cohort was defensive of what had been created rather than open to the prospect of newcomers and new ideas. There was a real fear of loss of livelihoods and any change to the status quo. One speaker pointed out that Maleny is 'not a dying rural town ... We're not motivated to become a book town to save the economy of the town' (Maleny Arts Council 2012). This was a substantial argument, and an 
important point to concede. It reaffirmed my findings elsewhere: that in Maleny there is insufficient hunger and willingness in the sector of the community where it really counts to take what is perceived as a risk to transform the town. Maleny has already experienced success on a number of fronts.

While the booksellers acknowledged that the town was 'an unofficial book town', from a business and marketing perspective, they preferred the multiple identities the town currently reflected to visitors: an organic food town, a wedding destination, a place with a vibrant arts community, a place known for national parks and wilderness, a place for short breaks 'that offers something to everyone'. I interpreted this support for diversity as incorporating a defensiveness of their position as 'the book people' in the town - an identity that granted them distinctiveness and one they were reluctant to share with others. I detected that this group equated the theming of a town with ugliness in some way - perhaps they saw that increased numbers of book-motivated tourists would result in an inability to control change in other parts of the community, and would threaten the beauty of the town and the wider environment. This assumption was understandable, despite the fact that care and protection of the unique rural environment are at the very heart of every other book town I have visited. There was also a lot of talk about the fate of individual specialist bookstores that had closed in other nearby places, which clustering ${ }^{3}$ would undoubtedly help overcome.

What was more surprising was the lack of confidence on the part of key stakeholders who worked in the sector and who were advocates for books in the community about the future of the printed book itself. A number of speakers cited the threats of internet book sales, their concern about the use of Kindles and other e-readers, and the statistics they had read about book sales in metropolitan centres being lower. They suggested that the idea of a book town 'might be a little passé in these times with retail being dominated by online buying' (Maleny Arts Council 2012). Another key stakeholder claimed that the book industry was in its 'death throes', despite the work that continued to be produced by publishers, authors and illustrators. A writer voiced concerns that the book was 'being pushed aside by the amount of things we do otherwise in our lives and we keep crowding in'.

Concerns were also raised about young local people not supporting writing events or sharing the book interests of older generations, although this was rebutted by one speaker's view that the growing status and presence of USC was encouraging a new trend for young people to stay in Maleny, which was described as 'a strong breeding ground for emerging artists'. While these are all valid points, I observed that some key members of this community were resistant to hearing about research on an initiative centred on books that is successfully sustaining small towns around the world, and is proving that such places are drawcards for the very kind of bookappreciating tourists that would share the Maleny community's appreciation and need to protect community and landscape in a positive way.

\section{Maleny and other rural book centres}

The case study of Maleny demonstrates that the book is an object of both comfort and contention.

Like the local currency, the bunya, the book is both a binding mechanism and a symbolic entity. The book demands slowness. It is enjoyed in Maleny, where it 
enhances community bonds and social capital. It fits well with a culture of wholesomeness that is sought by local people in their daily lives and also increasingly captivates the middle classes who enjoy time in this peaceful setting, despite the increasing challenges the community faces to maintain this ambience with rising costs and the threat of development. The book is a device that synthesises aspects of Maleny's unique culture and history: the place and the landscape, the intellectually engaged community's understandings of itself, and the various concentric circles of activity in Maleny that bring vitality, diversity and sustainability. Yet the book also has the potential to stimulate argument and division between the different cohorts in Maleny, because it is central to the maintenance of a pleasurable lifestyle that is about limiting growth and corralling change. Strong ties can make communities inward looking and resistant to new ideas from outside.

The Maleny case study reinforced my broader research findings. High levels of social capital are desirable for book town success, but other characteristics required are innovative, open and imaginative responses to project developments that demand some risk, a willingness to embrace change and also incorporate ideas from outside the community, and a belief in the capacity of the book to be a catalyst in this process. Most book towns are located in picturesque locales or sites with inherent architectural interest, but also in places that are economically depressed or declining rural communities. The economic difficulties in the years preceding their transformation were a large part of what made them good candidates for book town projects. The Book Town Movement has sprung out of adversity, not privilege. While Maleny's ambience and amenity for cultural tourists are of continuing appeal, book town success is more probable in a town like Clunes in Victoria, where there was a high level of need for a project to reinvigorate a town that had experienced the ravages of decline, drought and population drain.

In comparison, Maleny shares characteristics with the Southern Highlands south of Sydney, another rich hinterland area that has also experienced a growth of rural cultural offerings with an emphasis on local landmarks, festivals and community events with books at their centre. Both are important hubs of creativity. The Southern Highlands book town is a nucleus of rural townships and villages - Bowral, Berrima, Mittagong and Mossvale — that united their literary energies with the direction of book town expert Paul McShane to become Australia's first book town in 2000. The area uses its cluster of four towns, each with distinct character features, to contribute particular strengths. The towns of Bowral and Berrima, in particular, provide a contrast. Home to a string of 20 independent bookstores in and around Bong Bong Street, the Bradman Museum with its own well-stocked bookshop, and the famous springtime celebration, Tulip Time, the elegance of Bowral is immediately apparent. Cafes, restaurants and other businesses also thrive through their association with the literary themes of the area, and make a feature of local produce-inspired cuisine.

In particular, the Southern Highlands Book Town is distinctive for prioritising its many literary associations through the spatial manifestation of a BOOKtrail that meanders through the various towns, encouraging visitors to stop and look at literary places of interest, bookshops and other book-related businesses, as well as taking in scenic walks. Like Maleny to Brisbane, the area promotes itself as an inviting playground for literary-minded Sydneysiders with a penchant for antiquarian books, arts galleries, cafes, boutiques, cultivated gardens, stately homes 
and unique literary tourism pursuits (McShane 2010). A book trail is a concept that would potentially work well in the Blackall Ranges, as it also has a cluster of picturesque towns - Maleny, Montville, Flaxton, Mapleton, Palmwoods and Kenilworth. This would allow Maleny to maximise its book-related potential without the need to brand itself in a particular way, and is a gentler application of the book town concept that would emphasise the area's scenic lookouts, outdoor pursuits, wineries and other attractions in a way that would benefit the area as a whole.

A highlight of the BOOKtrail is Berklouws' ${ }^{4}$ distinctive Book Barn just outside Berrima, set among farm paddocks and filled to capacity with over 300,000 secondhand books (Berkelouw 2012). Travellers are invited to stay a day or a week, drink coffee, visit the cellar door and enjoy books beside a crackling log fire. Serious book collectors' needs are catered for in a rare antiquarian book room. The experience is interspersed with gems of rich literary history for the curious bibliophile, the literary tourist or the visitor seeking a meaningful or educative experience. Visits to this area, as to the Blackall Ranges, punctuate a slow travel experience in a satisfying way, allowing bookish immersion in the countryside.

Since 2007, Berkelouws has had success with another book tourism drawcard in Eumundi, another Sunshine Coast town closer to the coast where, with the support of local people, its new and secondhand book enterprise and café is flourishing as a destination for Sunshine Coast tourists and Brisbane people seeking a relaxing book-based experience. A wider Sunshine Coast book trail is therefore also a possible alternative for the broader Sunshine Coast region, drawing on the book and its potential to attract those seeking slow experiences reliant on desirable aspects of rural difference together with the upmarket aspects of urban replication that a multicultural new world city on the region's doorstep demands.

\section{Endnotes}

1 A book town is a 'location that celebrates the written word. And welcomes travellers whether they are avid readers, writers or merely browsers, wanting to visit a town with an extra twist. These towns and villages have a delightfully disproportionate number of second-hand and antiquarian bookshops, and sometimes have other associated businesses based on writing, reading and publishing. The idea is that a mainly rural town - in attractive surroundings and with historic interest - will find a new life through the book business by attracting well-read visitors' (Macaskill 2007: 2). Based on the success of the first book town, Hay-onWye in Wales, established by Richard Booth in 1961, A. V. (Tony) Seaton first wrote about book towns as successful peripheral tourism initiatives as he engineered the establishment of Scotland's National Book Town, Wigtown, in 1997 (Seaton 1996, 1999).

2 Other Maleny cooperatives have included Wastebusters - a recycling operation; Barung Landcare; and Crystal Waters - a community title scheme.

3 Clusters of bookshops and other book-related businesses in book towns, but also in creative quarters in urban centres, provide viability and prosperity through the provision of mutual financial, psychological and community support, 'increasing the efficiency of markets; bringing together buyers and sellers; creating overlap ... and stimulating competition, thereby generating "multiplier" effects, synergy, complementary interchanges and swapping of resources' (Landry 2008: xli). In book towns, each enterprise has its own specialty, which complements those of the others and builds a coherent book town identity that attracts collectors and book specialists as well as curious tourists and travellers. It is an economic approach that has worked to rekindle regional growth in a range of industries, not just bookselling. 
4 Berkelouws is Australia's longest established antiquarian bookstore, first established in Sydney in 1950. Prior to emigration to Australia, family members had been booksellers in Rotterdam, the Netherlands since 1812 (Berkelouw 2012).

\section{References}

Berkelouw L. 2012. Personal interview. Eumundi, Queensland. 14 August.

Bourdieu P. 1984. Distinction: A social critique of the judgement of taste. Cambridge, MA: Harvard University Press.

Bourdieu P. 1986. 'The forms of capital'. http://www.marxists.org/reference/subject/ philosophy/works/fr/bourdieu-forms-capital.htm, accessed 25 November 2010.

Dickenson J. and Lumsden L. 2010. Slow travel and tourism. London: Earthscan, 2010. Franklin A. 2008. A collector's year. Sydney: UNSW Press.

Givens C. 2015. Personal communication, 5 October.

Green G. 2004. 'Environment award for author's series.' Courier-Mail, 9 June, 18.

Hall C.M. 2009. 'Degrowing tourism: Décroissance, sustainable consumption and steady-state tourism'. Anatolia: An International Journal of Tourism and Hospitality Research 20(1) (2009): 46-61.

Landry C. 2008. The creative city: A toolkit for urban innovators (2nd ed.). London: Earthscan.

Lang S. 2015a. Personal communication, 30 October.

— 2015b. Outspoken [website], http://www.outspokenmaleny.com, accessed 25 September 2015.

Macaskill H. 2007. 'The complete guide to book towns'. The Independent [UK], 24 March, http://www.independent.co.uk/travel/uk/the-complete-guide-to-book-towns -441542.html, accessed 22 February 2010.

Mason J. 2002. Qualitative researching. London: Sage.

McCrum R. 2006. 'E-read all about it'. The Observer [UK], 15 January, http://www.guardian.co.uk/books/2006/jan/15/ebooks.technology/print, accessed 3 February 2011.

McGuire F., Boyd R. K. and Tedrick R. E. 1999. Leisure and aging: Ulyssean living in later life. Champaign, IL: Sagamore.

Maleny Arts Council 2012. 'Maleny - a book town?' Public Meeting, Maleny RSL Hall, 13 March.

McShane P. 2010. Personal interview, Bowral, New South Wales, 9 July.

Mulcock J. and Toussaint Y. 2002. 'Memories and idylls: Urban reflections on lost places and inner landscapes'. Transformations 2: 1-16.

Muller L. 2010. Personal interview, Brisbane, 7 September.

Onyx J. 2005. Maleny: Social capital and the development paradox. Sydney: University of Sydney CACOM.

Onyx J. and Bullen P. 2000. 'Measuring social capital in five communities'. Journal of Applied Behavioural Science. 31(1): 23-42.

Onyx J. and Leonard R. 2007. 'The Grey Nomad phenomenon: Changing the script of aging'. International Journal of Aging and Human Development 64(4): 381-98.

Putnam R. 1995. 'Bowling Alone: America's Declining Social Capital'. Journal of Democracy, 6(1): 65-78. 
Putnam R. 2000. Bowling alone: The collapse and revival of American community. New York: Simon and Schuster.

Radbourne J. 2015. Personal communication, 29 October.

Ragusa A. T. 2013. 'Downshifting or conspicuous consumption? A sociological examination of treechange as a manifestation of slow culture'. In N. Osbaldiston (ed.), Culture of the slow: Social deceleration in an accelerated world. London: Palgrave Macmillan.

Sassatelli R. 2013. 'Creativity takes time, critique needs space: Re-working the political investment of the consumer through pleasure', in N. Osbaldiston (ed.), Culture of the slow: Social deceleration in an accelerated world. London: Palgrave Macmillan.

Seaton A. V. 1996. 'Hay-on-Wye, the mouse that roared: Book towns and rural tourism'. Tourism Management, 17(5): 379-85.

Seaton A. V. 1999. 'Book towns as tourism developments in peripheral areas'. The International Journal of Tourism Research, 1(5): 389-99.

Seaton A. V. 2002. 'Tourism as a metempsychosis and metensomatosis: The personae of eternal recurrence', in G. M. S. Dann (ed.), The tourist as a metaphor for the social world. Wallingford: CAB.

Stafford A. 2005. 'The people versus Woolworths'. The Monthly, October: 22-3.

Tilden J. 1996. 'Bunyas and bladey grass: How the co-operative spirit thrives in Maleny, Queensland'. New Internationalist 278: 22-3.

Urry J. 1988. 'Cultural change and contemporary holiday-making.' Theory, Culture and Society 5(35): 35-55.

Zaid G. 2004. So many books. London: Sort of Books. 